\title{
DEVANEIOS DE UM LUGAR ${ }^{9}$
}

\section{DOI: http://dx.doi.org/10.18616/intcov58}

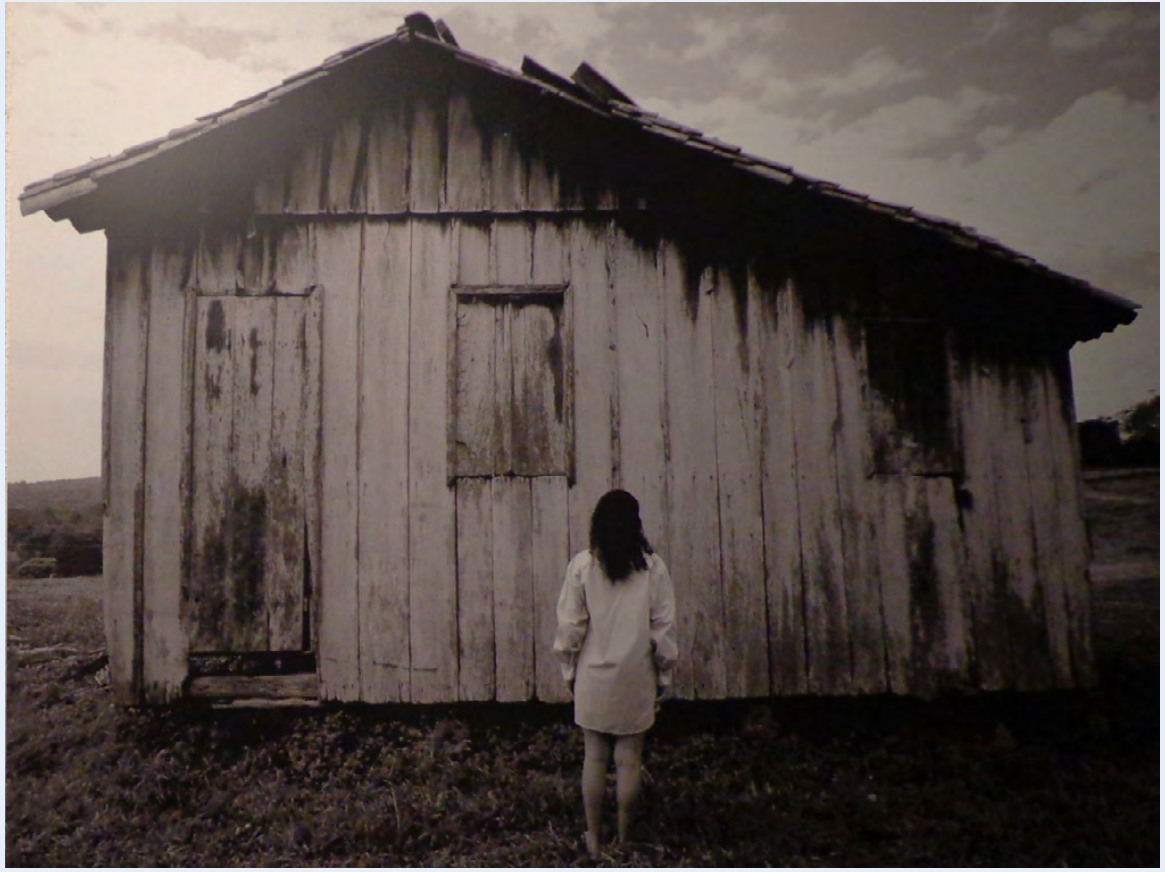

Créditos: Andressa Gomes Flor.

$\mathrm{R}$

A

O

9 Necessitamos de constante contato com outras pessoas. E, o distanciamento social mostra como somos frágeis. Porém, isso faz com que a percepção aflore os pensamentos. Na fotografia, congelar as lembranças e contemplar o tempo de interiorização com seu "eu", "meu" e "vossa" memória. 